\title{
Inanimate Subject Sentences in English and Their Translation Strategies*
}

\author{
Jiaosheng Qiu \\ Taishan University, China
}

\begin{abstract}
This paper first clarifies the concept of inanimate subject sentences in English, and points out that inanimate subject sentences refer to sentences that use verbs expressing material or psychological processes as predicates instead of living entities. Then the causes of inanimate tendencies of English subjects are explained from the perspective of Chinese and Western thinking. According to the different attributes of subjects, inanimate subject sentences can be divided into the following six categories: abstract concepts as subjects, nouns expressing psychological feelings as subjects, nouns indicating specific actions and action meanings are used as subjects, natural phenomena as subjects, concrete things as subjects and time and place nouns as subjects. Four examples are listed in each category. Then, the paper elaborates the linguistic effect of English inanimate subject sentences. Finally, according to the six categories of inanimate subject, it explores the translation strategies of English inanimate subject sentences, and defines the exceptional phenomena, with a view to helping readers in their English language learning.
\end{abstract}

Index Terms_-inanimate subject, inanimate subject sentence, translation strategy

\section{INTRODUCTION}

Most of the studies on inanimate subject sentences are scattered in foreign works on English grammar and vocabulary. The earliest thematic study in China began with Mr. Qian Gechuan. His book "English Difficulties in Detailed Explanation" gives a detailed analysis and solution to 200 English grammar and vocabulary problems. The first one is the discussion of inanimate subject sentences, while the name used is the name of inanimate subject sentences."The inanimate subject. Although the name was continued to be used later, it was not widely used. Zhang Jin and Chen Yunqing, who first used the name "inanimate subject" in China, have made a thorough study of it in the book Outline of English-Chinese Comparative Grammar.

English sentences with inanimate subjects refer to sentences that use verbs expressing material or psychological processes as predicates with entities (such as objects, abstract concepts and action nouns) that have no meaning of life as subjects (He Mingzhu, 2003). This concept clarifies two essential elements of English inanimate subject: the subject of the sentence is inanimate subject, also known as impersonal subject sentence, and the predicate is animate verb, which is relative to inanimate subject, referring to the action and action of people or social groups, such as See, find, bring, desert, meet, visit, witness, convince, request, compel, deny, prevent, admit, ask, allow, slip, escape, creep, delight, please, strike, amaze, astonish, surprise, worry, trouble, impress, satisfy, deprive, rob, etc. (Lian Shuneng, 2002).

English inanimate subject is a unique linguistic phenomenon in English. It is closely related to the national historical and cultural background and the way of thinking. Inanimate subject sentences are frequently used in formal English, especially in written English. The main reason is that Westerners emphasize object consciousness in their thinking. In order to explore the characteristics of English inanimate subjects and better understand the connotation and meaning of sentences where English inanimate subjects are located and the differences between English inanimate subjects and Chinese in grammatical use, this paper discusses and analyses the definition, characteristics and translation strategies of English inanimate subjects from the perspective of teaching practice and practicality.

\section{Causes of Sentences With InANimate SubJects}

The relationship between language and thinking has always been a topic of concern and discussion among linguists. It is generally believed that language is the main form of thinking, and the way of thinking restricts the structure of language. The difference of thinking mode is an important reason for the difference of language. Chinese and English are two carriers of Eastern and Western cultures, belonging to different language families and having different ways of thinking. Oriental traditional philosophical thought emphasizes "the unity of man and nature", "the unity of subject and

\footnotetext{
* Fund projects: Shandong Social Sciences Planning Research Project “Analysis and Mechanism of College Students' English Mobile Learning Adaptation from the Perspective of Dynamic System Theory" (17CWZJ16); Shandong Education Science Planning Project "Application of Mobile Micro learning Based on Mobile Phone Terminal in College English Teaching” (BCGW2017011); Taishan University Teaching Reform Project "Research on the Application Practice and Effect of Mobile Learning Mode of College English Based on Smart-phones" (201617), "Application of Project-based Approach to College English Teaching in Local Colleges" (201738).
} 
object" and "the whole"; while western traditional philosophical thought emphasizes "the separation of subject and object", "the separation of characters" and "the individual". The two philosophical concepts are reflected in thinking: Chinese people who are accustomed to subjective thinking tend to understand, explain and describe things in the objective world from their own point of view, so that language expression has the characteristics of subjectivity. In Chinese, the idea of human being as the soul of all things always occupies the dominant position, so Chinese is more commonly used in personal subject expression, focusing on "who is what". When the person is self-evident, it refers to the person in general terms of "someone", "people" and "everybody". The subject of animation always occupies an absolute advantage; while the Anglo-American people who are accustomed to the object mode of thinking often put the point of view of observation or narration in line. In English, people often pay attention to "what happens to whom" because of the objectivity of language expression in terms of action, result or recipient. Subject is usually the most concerned and interesting thing, people will undoubtedly use the corresponding inanimate noun as the subject of a sentence. The peculiar Western way of thinking and the characteristics of English language itself lead to the emergence of a large number of inanimate sentences in English expression. The fact that there are many inanimate subjects in English and few inanimate subjects in Chinese reflects the great differences in thinking patterns between English and Chinese.

Regarding the reasons for the ineffectiveness of English subjects, Chen Yu (2008) believes that the main reason is the way of thinking. Chinese people are accustomed to subjective thinking. Traditional ideas such as "man is the soul of all things" and "man is destined to conquer nature" have always been dominant, and thinking determines language. Therefore, more ways of expression in Chinese are "who did (what happened)". There are many sentences with subject, that is to say, the sentences with animate subject in Chinese have absolute advantages.

On the contrary, Westerners are accustomed to object thinking. They often put the viewpoint of observation or narration on the result of actions or actions or the recipient, which makes language expression have the characteristics of objectivity (Chen Yu, 2008). Therefore, the most common way of expression in English is "what happens to whom". They will put the most concerned and important content at the beginning of the sentence as the subject. Obviously, these subjects are "ineffective". In order to describe the specific situation of "happening" on these subjects, the predicate must be "animate". Thus, there are more cases of inactive subject sentences in English.

Most of the rhetorical devices discussed in traditional rhetoric are used in written language to make the language more vivid. Some commonly used rhetoric devices, such as personification, metonymy and synecdoche, make language express vivid images by giving life to inanimate things, or by saying that a thing refers to a thing or a thing, or by substituting part for all. In order to cooperate with the use of these rhetorical devices and achieve the goal of expressing vividly, a large number of inanimate subject sentences have emerged in written English.

With the continuous development of linguistics, people find that traditional rhetoric is confined to the limitations of its formal study. It focuses mainly on the classification and division of figures of speech, lays particular emphasis on the analysis of language forms themselves, and separates language, cognition and society. Therefore, it can not truly reflect the objective world (Xie Zhijun, 2000). Modern linguistic studies have shown that metaphor is not only a skill of using language effectively, but also a basic method of observing and understanding the world. Contemporary

In his book Metaphors We Live By (1980), co-authored by G. Lakoff, a cognitive linguist, points out: "Metaphors exist in our daily life, not only in language, but also in our thoughts and actions. The general conceptual system on which we rely for thinking and action is fundamentally metaphorical. The essence of Lakoff's theory of "con-ceptual metaphor" is that there are always two cognitive domains in the process of people's understanding of the world, one of which always maps to another, which is his famous concept mapping.

In addition, some researchers (Sheng Limin, 2015) believe that the phenomenon of English subject inactivation is mainly influenced by Western rational thinking, especially in formal style, inactive subject phenomenon is particularly prominent in order to show its objectivity and impartiality.

\section{TyPeS OF SENTENCES WITH INANIMATE SUBJECTS}

According to the different attributes of the subject, inanimate subject sentences can be divided into the following six categories:

1) Subjects are abstract concepts

Subjects of this kind of inanimate subject sentences are usually abstract nouns, and the predicate verbs are also personified animated verbs.

Example 1: Modesty helps one go forward, where as conceit makes one lag behind.

Example 2: The stillness consequent on the cessation of the rumbling and laboring of the coach, added to the stillness of the night, made it very quiet indeed. (Charles Dickens: A Tales of Two Cities)

Example 3: Her vanity left her heavily in debt.

Example 4: Haste makes waste.

2) Subjects are nouns expressing psychological feeling

Unlike the former one, although subjects in this kind of inanimate subject sentence are not only abstract nouns, but also abstract nouns which express emotional state, such as sadness, loneliness, discontentment, fear, astonishment, excitement, etc. Of course, predicate verbs are usually personified animated verbs, too. 
Example 5: While he managed to get up every morning and face the day ahead, a repeated discontentment with his life took a toll, and his depression became integral to his being: the norm.

Example 6: The fear of being labeled and perceived differently kept him from talking about it and from seeking help and treatment.

Example 7: The astonishment robbed me of my power of speech.

Example 8: Excitement deprived me of all power of utterance.

3) Subjects are nouns expressing specific actions

This kind of inanimate noun is usually the noun form of the verb (such as sight, discovery, arrival, etc.) or the noun with verb meaning (idea, thought, etc.). These words usually form the subject of the inanimate subject sentence together with other modifiers, and form a logical subject-predicate or verb-object relationship with the modifiers before and after them. For example, "the teacher's arrival" (subject-predicate relationship), "the implementation of the plan" (verb-object relationship) and so on.

Example 9: A comparison of the two methods will show you their advantages and disadvantages.

Example 10: Seeking help is critical, as depression can lead to thoughts of suicide.

Example 11: This report offers the most specific and accurate description of the problems.

Example 12: Studies have shown that Hartoonian is far from alone.

4) Subjects are nouns expressing natural phenomena of weather

This kind of inanimate noun usually refers to the natural phenomena of weather, such as wind, rain, snowstorm, etc. The predicate in the sentence often uses personification rhetoric.

Example 13: Storms have hitting almost all of Britain recently

Example 14: Hurricane Andrew was last night heading into the Gulf of Mexico.

Example 15: Super Typhoon Mangkhut hit the main island of Luzon in Philippines yesterday.

Example 16: Light rain extends from South Sichuan to central Yunnan.

\section{5) Subjects are nouns expressing concrete things}

The subject of this kind of sentence is usually some nouns that express things, such as TV, desk, chair, classroom, etc. The predicate of this kind of inanimate subject sentence is often acted by some animate verbs, which makes the sentence have personification rhetoric effect, makes the language more vivid and gives people a kind of association.

Example 17: The painting immediate reminds me of my childhood in my home.

Example 18: Motherland always draws the heart of overseas Chinese.

Example 19: An American College Health Association report found that 1.5 percent of 16,000 students have attempted suicide.

Example 20: Her name always slips my mind.

6) Subjects are nouns of time and places

This sentence pattern usually takes the noun of time or place as the subject, such as Chicago, Xi-an, 2008, etc. The predicate is usually see, witness, find, tell and other animated verbs. Personification is also used in this kind of sentences.

Example 21: Xi-an witnessed many great historic events.

Example 22: September 2018 found me studying in Los Angeles.

Example 23: 2008 saw the hosting the Olympic Games in Beijing.

Example 24: Chicago takes on Houston in the final.

\section{EFFECT OF INACTIVE SUbJECT SENTENCES}

Zhang Zhizhong (2003) believes that abstract nouns as subjects can make the language concise, powerful and vivid; inanimate nouns as subjects can make the language anthropomorphic and appealing. In addition, the use of inanimate subjects can also make the expression more concise and objective. Classical sentences such as "Haste makes waste." and "Her name always slips my mind." can not only express the meaning clearly, but also succinctly, objectively, anthropomorphic and appealing.

\section{TRANSLATion Strategies of InANimate SubJeCt SENTENCES}

Because of the difference of thinking between English and Chinese, Chinese is accustomed to using the living person as the subject, while English has a large number of sentences with inanimate nouns as the subject. Therefore, when translating English inanimate subjects, we must take into account the expression habit of Chinese and make appropriate adjustments to the subject of the original text so as to make it conform to Chinese thinking.

For the translation of inanimate subject sentences, many researchers have given their own translation methods (He Mingzhu, 2003; Lian Shuneng, 2002; Zhang Zhizhong, 2003; Chen Yu, 2008; Sun Jingfang, 2011). This paper tries to elaborate the strategies of Chinese translation of Inanimate subject sentences in English according to the categories of inanimate subject:

1) The abstract concept as the subject

Translation strategies: retain the original inanimate subject, add causative usage, and translate the sentences as "A 
使 B....”:

Example 1: 谦虚使人进步, 骄傲使人落后。

Example 2: 由辘辘轮声的突然中断而造成的寂静使原本宁静的夜晚更加幽静无比。

Example 3: 虚荣心使她负债累累。

Exceptions: Example 4"Haste makes waste" is a very common English proverb. If it is translated into "勿忙使（人） 浪费" according to the rules, it seems verbose and ambiguous. Therefore, in translating such proverbial inanimate subject sentences, we must be faithful to the original implicature, which can break the traditional sentence structure and translate directly into“欲速则不达”.

\section{2) Nouns expressing psychological feelings as subjects}

In fact, the noun expressing psychological emotion is also an abstract noun. This paper distinguishes it from the first kind of "abstract concept" because there are two ways of translating inanimate subject sentences of psychological emotion.

The first one is to translate directly into causative sentences, the same as Category 1.

Example 5: 尽管他每天早晨尽力起床面对新的一天, 但索绕心头的对人生的的不满却使他付出了严重的代价, 以至于抑郁已经成为他生活中挥之不去的一部分, 成为一种常态。

Example 6: 害怕被视为异类、另眼相看的担忧使他不去谈论它, 也不去寻求帮助和治疗。

Example 7: 惊讶使我丧失了说话的能力。

Example 8: 兴奋使我失去了说话的全部力量。

The second is to change Inanimate subject sentences in English into Chinese inanimate subject sentences when people are referred to as subjects in Chinese translation.

Example 5: 尽管他每天早晨都尽力起床面对新的一天, 但他受到索绕在自己心头的对人生的不满情绪的严重 影响, 以至于抑有已经成为他生活中挥之不去的一部分, 成为一种常态。

Example 6: 因为他害怕被视为异类、另眼相看, 所以他既不敢谈论，也不去寻求治疗和帮助。

Example 7: 我惊讶得说不出话来。

Example 8: 我兴奋得说不出话来。

3) Subjects are nouns expressing the meanings of specific actions and actions.

Translation strategies: English inanimate subjects are translated directly into Chinese subjects, and personified translation is adopted when necessary.

Example 9: 对这两种方法的比较将显示出它们的优点和缺点。

Example 10: 寻求帮助是十分重要的, 因为抑有症会导致自杀念头的出现。

Example 11: 该报告对问题进行了最具体、最准确的描述。

Example 12: 研究显示, 哈图年这样的情况绝非个案。

\section{4) Natural phenomena as subjects}

Translation strategies: There are two ways to translate inanimate subject sentences with natural phenomena as subjects. When translating, we should clarify whether they are active sentences or passive sentences according to the needs of the text. If they are active sentences, they are generally "inanimate subject + personified predicate..." If it is a passive sentence, the inanimate subject in English becomes the agent in the Chinese translation, which is generally translated as “......遭 (受) 到了.......的......”.

Example 13: 最近几乎整个英国都遭到了暴风雨的侵袭。(被动句)

Example 14: 昨晚, 煁风“安德鲁”进入了墨西哥湾。(主动句)

Example 15: 超级台风山竹昨日袭击了菲律宾吕宋岛的主要岛屿。(主动句)

Exceptions: Weather Forecast

Because of the particularity of weather forecast, this kind of sentence must abandon the inanimate subject, make the sentence lose its "spirituality" and replace the subject and object components in Inanimate subject sentences in English.

Example 16:

Light rain extends from South Sichuan to central Yunnan. This sentence can be translated as “四川南部到云南中部 有小雨” That is to say, In the original sentence, "rain" as the subject is translated into the object, while "south Sichuan to central Yunnan" in the original sentence is translated into the subject.

\section{5) Specific things as subjects}

Translation strategy: English "inanimate subject" is translated literally into Chinese "inanimate subject", and the predicate is translated by personification.

Example 17: 这幅画立刻使我想起了在家乡度过的童年时光。

Example 18: 祖国时刻牵动着海外华人的心。

Example 19: 一份美国大学健康协会的报告显示, 1.6 万名学生中, 有 $1.5 \%$ 的人曾经尝试过自杀。

Exceptions: English slang

"Her name is always slips my mind." It's a typical English slang sentence. According to the translation strategy above, 
it can be translated into “她的名字总是从我心里滑落”. It's only a literal meaning, of course, it means I can't remember her name, which can be translated as “我总是记不住她的名字”.

6) Time and place nouns as subjects

This kind of English inanimate subject sentence is relatively simple to translate into Chinese. Generally, time or place can be translated directly into adverbial in Chinese, sometimes into Chinese subject, and the predicate uses personification rhetoric.

Example 21:

在西安发生了很多重大的历史事件。

As a noun, $\mathrm{Xi}$-an is used as an adverbial in the Chinese version.

西安目睹（见证）了很多重大的历史事件的发生。

In this version, $\mathrm{Xi}$-an is used as an subject in the sentence.

Example 22:

2018 年 9 月, 我在洛杉矶学习。

As a noun, September 2018 is used as an adverbial in the Chinese version.

Example 23:

2008 年奥运会在北京举办。

In this sentence, 2008 is also used as adverbial.

Exceptions:

Example 24: Chicago takes on Houston in the final.

In this sentence, "Chicago" and "Houston" are apparently place nouns, but in fact they refer to the NBA teams“公牛 队”,and“火箭队”in the two cities. It is absolutely undesirable to translate them mechanically into adverbials. The correct translation is: 芝加哥（公牛队）在决赛中对阵休斯敦（火箭队）.

\section{CONCLUSION}

To sum up, as a special phenomenon in English written texts, inanimate subject is a common and unique grammatical phenomenon in English. It has the characteristics of diverse sentence patterns, rigorous structure, high vocabulary density and objective and vivid expression. It is different from Chinese in grammatical structure and expression habits. Understanding the characteristics of inanimate subject mentioned above will help learners in the process of English-Chinese translation. Better and more accurate use of English inanimate subjects, so that the translation is smooth, vivid and in line with language expression habits. This paper discusses the concept, causes, categories, effects and translation strategies of Inanimate subject sentences in English. There are many categories of Inanimate subject sentences in English. In actual translation, we must distinguish between specific situations. According to the three principles of "faithfulness, expressiveness and elegance", we must not copy one translation strategy mechanically to cause mistranslation. Sentences with inanimate subject, on the surface, are only a way of sentence making or a type of sentence, and a linguistic phenomenon at the micro level. However, if we want to make a comprehensive, systematic and in-depth study of them, we should deal with lexicology, semantics, pragmatics, rhetoric, stylistics, comparative linguistics, translatology, psycholinguistics, cognitive linguistics, systemic-functional linguistics and corpus. Many disciplines, such as library linguistics, thinking and statistics, are concerned about. Therefore, the study of Inanimate subject sentences in English is of great theoretical and practical value, but also of great challenge. It requires a solid linguistic theoretical basis and perseverance to achieve new research results. Only by constantly expanding research content and innovating research methods and exploring ways of language from one to the other, from small to big, comprehensive and systematic, can we have a bright future for the study of Inanimate subject sentences in English.

\section{REFERENCES}

[1] Chen Yu. (2008). On the Chinese Translation of Inactive Subjects from the Perspective of Differences of Thinking between English and Chinese. Journal of Yibin University, 09, 96-98.

[2] He Mingzhu. (2003). Understanding and Translation of English Inactive Subject Sentences. Foreign Language Teaching, 05, $51-55$.

[3] He Mingzhu. (2003). Comparison of English Inactive Subject Sentences and English-Chinese Thinking Characteristics. Journal of Zhuzhou Normal College, 04, 75-77.

[4] He Mingzhu. (2009). Cognitive salience analysis of Inanimate subject sentences in English. Foreign language teaching, 05, 37-39.

[5] He Mingzhu. (2009). An Analysis of the Implicit Logical Semantic Relations of English Inactive Subject Sentences. Journal of Hunan University of Technology (Social Science Edition),03,88-91.

[6] He Mingzhu. (2013). A Study of English Passive Subject Proverbs. Language Education, 02, 51-55.

[7] Jiang Yuqin. (2015). Contrast and Translation of Adverbials between English and Chinese. Journal of Yichun University, 11, 97-100.

[8] Lian Shuneng. (2002). On Chinese and Western Ways of Thinking. Foreign Language and Foreign Language Teaching, 02, 40-46+63-64.

[9] Sun Jingfang. (2011). English Inactive Subject: Function, Classification and Translation. Overseas English, 13,191+193. 
[10] Wang Xueying. (2014). Image Translation of English Inactive Subjects. Foreign Language Studies, 04, 24-29+105.

[11] Wu Qun. (2002). Semantic coherence and sentence flexibility: grasping the conversion of personal and material names. Chinese Translators Journal, 04, 86-89.

[12] Zhang Zhizhong. (2003). "Inanimate Subject" and Translation. English Studies, Z1, 65-69+136.

Jiaosheng Qiu was born in Tengzhou, China in 1983. He received his master's degree in foreign linguistics and applied linguistics from Shandong Agricultural University, China in 2012.

He is currently a lecturer in the Department of College Foreign Languages Teaching, Taishan University, Tai'an, China. His research interests include Second Language Acquisition and College English Teaching. 